\title{
Uvod v kognitivni trening
}

\author{
Vojko Kavčič ${ }^{*}$ \\ Institute of Gerontology, Wayne State University, Detroit, Michigan, ZDA \\ Mednarodni inštitut za aplikativno gerontologijo, Ljubljana
}

\begin{abstract}
Povzetek: V zadnjih nekaj desetletjih se je izredno povečalo zanimanje za kognitivni trening in njegovo uporabo. Kognitivni trening (KT), ki je pogosto omenjen tudi kot umovadba, možganski trening ipd., opredeljujemo kot vodeno vadbo specifičnih nalog, običajno strukturiranih, z namenom izboljšanja umskih sposobnosti. Posamezniki lahko vadijo različne kognitivne procese, od pozornosti do različnih vrst spomina, izvršilnih sposobnosti, hitrosti procesiranja informacij in reševanja problemov. $\mathrm{V}$ tem članku je predstavljenih nekaj temeljnih značilnosti KT. Po kratki predstavitvi zgodovinskega ozadja KT sledi opis osnovnih parametrov KT, povzetih po metaanalizi Lampita idr. (2014). Posebej je predstavljen računalniški KT in njegove prednosti. Večina članka je namenjena razpravi o kriterijih za opredelitev uspešnosti kognitivnih treningov, s poudarkom na trajanju učinkov KT in daljnem transferu, tj. izboljšanju tistih umskih sposobnosti, ki niso bile neposredno vključene v KT. Omenjena je tudi nevroplastičnost kot možganska podlaga KT. Članek zaključuje, da bo potrebnih še veliko študij, ki bodo natančneje preučile vse potrebne lastnosti KT za dober, učinkovit in trajnejši uspeh, kakor tudi študij, ki bodo natančneje preučile izbor izhodnih mer za zanesljivo in veljavno merjenje učinkov KT. Področje KT je kljub vsemu obetavno področje psihologije, nevroznanosti in sorodnih disciplin, ki lahko veliko prispeva posamezniku in družbi.
\end{abstract}

Ključne besede: kognitivni trening, transfer, daljni transfer, nevroplastičnost

\section{Introduction to cognitive training}

\author{
Vojko Kavčič ${ }^{*}$ \\ Institute of Gerontology, Wayne State University, Detroit, Michigan, USA \\ International Institute of Applied Gerontology, Ljubljana, Slovenia
}

\begin{abstract}
Over the past few decades, there has been an increased interest in cognitive training and its use. Cognitive or brain training (CT) is defined as guided training in specific tasks, usually structured, with the intention of improving individuals' cognitive abilities while engaging specific cognitive processes, such as attention, memory processes, executive functioning, information processing, or problem solving. This paper presents basic features of CT. A short description of the historical background of CT is given, followed by a description of basic CT parameters as summarized from a meta-analysis published by Lampit et al. (2014). Computerized CT and its advantages are presented as well. The bulk of the paper is dedicated to a discussion of CT effectiveness with emphasis on effectiveness and duration of CT-associated changes and far transfer (i.e., improvement of those cognitive abilities that were not directly engaged during CT training). Neuroplasticity, the presumptive brain underpinning of CT, is introduced. The final conclusion is that there is still a significant need for additional studies that will investigate the different facets of CT, so as to best ensure effective planning and durable outcomes for CT. In addition, there is a need for studies to investigate the best selection of outcome measures for evaluation of CT effectiveness to most clearly demonstrate reliable and valid outcomes. The area of CT, combining important fields, including psychology, neuroscience and other related disciplines, has an optimistic future and can contribute importantly to both the individual and societal level.
\end{abstract}

Keywords: cognitive training, transfer, far transfer, neuroplasticity

\footnotetext{
"Naslov/Address: dr. Vojko Kavčič, Wayne State University, Institute of Gerontology, 87 E. Ferry Street, Detroit, MI 48202, ZDA, e-mail:voykok@gmail.com
}

Članek je licenciran pod pogoji Creative Commons Attribution 4.0 International licence. (CC-BY licenca). The article is licensed under a Creative Commons Attribution 4.0 International License (CC-BY license). 
V zadnjih treh desetletjih se je izredno povečalo zanimanje za kognitivni trening in njegovo uporabo. Kognitivni trening (KT), ki je pogosto imenovan tudi umovadba, možganski trening, nevrofit ipd., je običajno opredeljen kot vodena vadba specifičnih nalog, običajno strukturiranih, $\mathrm{z}$ namenom, da posamezniki vadijo dokaj natančno opredeljene kognitivne procese in sposobnosti, od pozornosti (sposobnosti osredotočenja na relevantne informacije) pa do različnih vrst spomina - kratkotrajnega, delovnega (sposobnosti hranjenja pomembnih podatkov za izvajanje trenutne naloge), dolgotrajnega - in izvršilnih sposobnosti (sposobnosti, potrebnih za nadzor in upravljanje $\mathrm{z}$ našimi mislimi in dejanji) ter hitrosti procesiranja informacij in reševanja problemov (Bahar-Fuchs idr., 2019). Cilj KT je izboljšati umske sposobnosti. Bolj poljudno rečeno, KT naj bi nas naredil bolj pametne, izboljšal naše kognitivne sposobnosti in omogočil učinkovitejše učenje.

KT temelji na predpostavki, da se lahko kognitivna kapaciteta, ali pa vsaj nekatere umske sposobnosti, kot sta delovni spomin ali hitrost procesiranja informacij, izboljšajo po angažiranju in vlaganju energije $\mathrm{v}$ zahtevne umske procese in vadbo. Poleg tega naj bi ta kognitivna angažiranost oziroma umovadba vsebovala takšne kognitivne procese, ki so potrebni in nujni v vsakdanjih aktivnostih.

KT lahko izvajamo bodisi $\mathrm{v}$ obliki individualnih vadb bodisi vadb v skupini, lahko pa tudi s pomočjo družinskega člana, negovalca ali s pomočjo strokovnega terapevta (Neely idr., 2009). Na začetku je KT slonel predvsem na uporabi nalog $\mathrm{v}$ papirnati obliki ali $\mathrm{v}$ obliki delovnih zvezkov, $\mathrm{v}$ zadnjih dveh desetletjih pa je večina KT $\mathrm{v}$ obliki računalniškega kognitivnega treninga (RKT). KT torej sledi razvoju tehnologije in je povezan $\mathrm{z}$ razvojem video iger (Anguera in Gazzaley, 2015).

Obstaja veliko študij in poročil o KT in RKT, in sicer na otrocih, mlajših odraslih in starejših odraslih, ki so bili bodisi kognitivno zdravi ali pa kognitivno oškodovani. Te študije so običajno pokazale, da KT vodi k izboljšanju tistih kognitivnih sposobnosti, na katerih je KT osnovan oziroma ki jih vključuje, manj pa izboljša tiste kognitivne sposobnosti, ki niso bile neposredno vključene v KT (za pregled glej Bahar-Fuchs idr., 2019; Lampit idr., 2014). Konkretneje, KT za delovni spomin bo izboljšal dosežke na nevropsiholoških testih za merjenje delovnega spomina, ne pa tudi na testih za merjenje hitrosti procesiranja informacij, in obratno. Ti dve vrsti učinkov KT strokovno imenujemo bližnji in daljni transfer. Bližnji transfer se nanaša na prenos, generalizacijo sposobnosti od treninga na mere uspešnosti treninga: če se izboljšanje umskih sposobnosti po treningu pokaže na testih treniranih sposobnosti ali sposobnosti, ki so treniranim podobne, govorimo o bližnjem transferu, če izmerimo izboljšanje na umski sposobnosti, ki ni bila vključena v KT, pa govorimo o daljnem transferu. Z drugimi besedami, definicija transfera je odvisna od podobnosti umskih komponent, ki jih zajemajo KT ali RKT in zaključne meritve (Sala idr., 2019).

\section{Ozadje kognitivnega treninga}

KT v širšem pomenu ima dolgo zgodovino, saj so se morda že v antičnih časih, zelo verjetno pa še prej, spraševali o učinkih ponavljanja ne samo na izboljšanje fizičnih spretnosti, ampak tudi umskih kapacitet. Antični izrek "Repetitio mater studiorum est" je bil v rabi že pred antičnim Rimom. Prevod bi se glasil: "Ponavljanje je mati učenja." Ta izrek še vedno velja. Veljalo bi omeniti še antične mnemonične tehnike kot učinkovito orodje za učenje oratorstva (Kavčič, 2015).

V širše zgodovinsko ozadje lahko štejemo začetne študije in razmišljanja s področja psihologije in pedagogike na začetku prejšnjega stoletja, ko so se raziskovalci ne samo začeli spraševati o osnovah učenja in umovadbe (angl. mindtraining), ampak so izvedli prve tozadevne eksperimente (za pregled glej Katz idr., 2018). V ožjem pomenu besede pa ima KT kot novo področje v okviru kognitivnih znanosti in nevroznanosti dosti krajšo zgodovino, ki se je začela $s$ koncem prejšnjega stoletja. Na razcvet KT sta vplivali dve področji: področje nevropsihološke rehabilitacije (Diller idr., 1974) in področje kognitivne nevroznanosti, bolj specifično raziskave o vplivu okolja na možganske strukture in funkcije (Elias in Wagster, 2007; Hannan, 2014).

\section{Začetki kognitivnega treninga, kot ga pojmujemo danes}

Prve publikacije o KT so se pojavile že v 80. letih prejšnjega stoletja, in sicer najprej s starejšimi odraslimi s kognitivnimi motnjami (npr. Zarit idr., 1981), kasneje pa z osebami z demenco (npr. Beck idr., 1988). Nato je prišlo do eksplozije objav o KT, v zadnjem desetletju pa predvsem objav o RKT. Tako obstaja trenutno skoraj nepregledno število publikacij o KT/RKT z različnimi, pogosto celo nasprotujočimi si ugotovitvami.

Ena izmed rešitev, kako priti do zanesljivejših zaključkov in konsenza glede učinka različnih vsebin KT, so metaanalize. Namen le-teh je na podlagi standardiziranih statističnih pristopov združiti rezultate več študij in s tem povečati statistično moč ter tako izboljšati oceno učinkovitosti KT, kar naj bi vodilo v zanesljivejše zaključke o učinku treniranja specifične domene. $Z$ najširšega vidika naj bi metaanalize pomagale pri izbiri najprimernejše metodologije $\mathrm{KT}$, to je izbire vaj za specifično kognitivno področje, izbiro najustreznejših začetnih in zaključnih nevropsiholoških testov ipd., kar naj bi vse pripomoglo k povečani učinkovitosti KT. A celo za metaanalize s področja KT/RKT lahko rečemo, da je prava poplava le-teh, in celo te prihajajo do nasprotujočih si zaključkov o učinkovitosti različnih lastnosti KT/RKT, tako da področje KT/RKT še vedno išče končne odgovore. Obstajajo tudi že t. i. metaanalize metaanaliz. Sala s sodelavci (2019) je izvedel metaanalizo metaanaliz s področja treniranja delovnega spomina in ugotovil, da v povprečju prihaja do bližnjega transfera, ni pa moč zaznati daljnega transfera $\mathrm{s}$ treningom delovnega spomina. Avtorji so povzeli, da se s treningom da vplivati na kognitivne sposobnosti, vendar je doprinos v veliki meri omejen na trenirano sposobnost.

Januarja 2020 sem v podatkovni bazi PsycInfo poiskal obstoječe metaanalize in pregledne članke s področja KT/ RKT. S ključnima besedama "metaanaliza" in "kognitivni trening" je bilo kar 65 zadetkov. Pri tem je treba poudariti, da je toliko zadetkov izšlo iz ene same podatkovne baze in uporabe specifičnih besed oz. besednih zvez, vendar bi lahko iskanje razširili še na druge baze, npr. Medline, Cochrane, 
in uporabili tudi druge ključne besede oz. besedne zveze, npr. "brain training" ali "video training" ali "computer training". Teh zadetkov bi bilo verjetno več, če bi izvedli širši konceptualni pregled ali uporabili še druge bibliografske baze.

Med množico metaanalitičnih člankov o KT sem za podrobnejši opis izsledkov v tem članku izbral metaanalizo, ki jo je opravil Lampit s sodelavci (2014). Za podrobnejšo predstavitev te metaanalize sem se odločil, ker je ena najboljših, najbolj sistematičnih s področja RKT. Vključuje zelo natančne kriterije za vključitev posamezne študije v metaanalizo in poda vrsto koristnih nasvetov za kvalitetno izvedbo RKT. V metaanalizo so bile vključene le študije, v katerih je RKT kumulativno trajal najmanj 4 ure. Tako je bilo vanjo vključenih 52 člankov s skupaj več kot 5.000 kognitivno zdravimi starejšimi posamezniki. Metaanaliza je pokazala pomembno izboljšanje umskega funkcioniranja pri tistih, ki so bili deležni RKT, pri kar 51 od 52 študij. Velikost učinka je bila majhna (Hedgesov $g=.22$ ), vendar statistično značilna. Avtorji so tudi ocenili verjetnost vpliva pristranskega objavljanja (angl. publication bias) in ugotovili, da do tega ni prišlo (Lampit idr., 2015). Bolj specifično, pomembno izboljšanje je bilo izmerjeno na testih delovnega spomina (prisotno je bilo v 28 študijah), neverbalnega spomina (prisotno v 13 študijah), hitrosti procesiranja informacij (prisotno v 33 študijah), in vidnozaznavnih sposobnostih (prisotno v 29 študijah). Presenetljivo pa metaanaliza ni pokazala pomembnega izboljšanja po RKT na testih pozornosti in izvršilnih sposobnosti. Morda je še bolj pomembno navesti ugotovitve, kateri so bili tisti parametri RKT, ki ne zagotavljajo učinkovitosti RKT: izvajanje RKT prek interneta na domu ni učinkovito, kakor tudi ne vadbe, ki so krajše od 30 minut, in treningi z več kot tremi vadbami na teden (Lampit idr., 2014, str. 13). Avtorji razlagajo (Lampit idr., 2015), da vadba, ki jo izvajamo več kot trikrat na teden, lahko pripelje do kognitivne utrujenosti, ki moti in lahko celo zmanjšuje dosežke na treningu. $\mathrm{Z}$ drugimi besedami, za učinkovit RKT, ki je vsebinsko osnovan bodisi za vadbo posamezne kognitivne sposobnosti (npr. delovnega spomina ali hitrosti procesiranja informacij) ali pa je multidomenski ali v obliki virtualne video igre, je treba imeti tedensko eno do dve vadbi, ki sta daljši od 30 minut, skupaj najmanj 8 do 10 vadb.

\section{Računalniški kognitivni trening (RKT)}

Z razvojem računalniške tehnologije je prišlo do rabe lete za izvajanje KT in tako je nastal računalniški kognitivni trening - RKT. Večina začetnega materiala za KT, predvsem delovni zvezki z različnimi nalogami, je bila prenesena na računalnike ali pa kasneje na spletne strani. Ta "digitalni" pristop je povečal prisotnost KT in omogočil prost dostop do programov vadbe in video iger. Kmalu zatem se je začela komercializacija programov RKT in trenutno je na razpolago cela vrsta takšnih komercialnih programov, od Lumosity, Learning RX, Posit Science, Cogmed do Nintendo Wii, PlayStation in Microsoftovih Xbox iger (glej pregled v Simons idr., 2016).

Področje RKT je relativno mlado, staro nekaj več kot dve desetletji, in tako še vedno poteka vrsta študij o izvedljivosti RKT na računalnikih, tablicah ali prek strežnikov ter tudi o učinkovitosti in prisotnosti transfera pri RKT. Trenutno lahko rečemo, da je prednost RKT, da omogoča: (i) lahko predstavljivost, večji izbor nalog, (ii) adaptivnost, to je nadzorovano povečevanje težavnosti naloge, (iii) rabo nalog za vadbo hitrega procesiranja informacij, pozornosti, in (iv) neposredno merjenje storilnosti in tudi takojšnjo povratno informacijo o ne/pravilnosti odgovora.

Poleg navedenih prednosti RKT $\mathrm{v}$ primerjavi $\mathrm{s}$ tradicionalnim KT je treba omeniti tudi, da je slednji standardiziran v smislu, da poteka enako za vse udeležence (angl. one size fits all), da predstavlja za posameznika večje zahteve, saj mora priti do lokacije, kjer se ta KT izvaja (seveda to drži tudi za RKT, če se ga izvaja v računalniških učilnicah in ne individualno), poleg tega pa je za takšno vadbo treba imeti kvalificirane izvajalce. RKT se tem pomanjkljivostim lahko izogne.

\section{Ali kognitivni trening/računalniški kognitivni trening (KT/RKT) deluje?}

KT oziroma RKT je bil izveden in proučevan na mlajših in starejših posameznikih, na kognitivno zdravih in oškodovanih. Posamezne študije in tudi metaanalize so pokazale, da RKT izboljša trenirane kognitivne sposobnosti, medtem ko je izboljšanje na netreniranih kognitivnih funkcijah majhno ali pa celo zanemarljivo. Vrste KT/RKT in študije o njihovi učinkovitosti se razlikujejo po velikem številu dimenzij: po vsebini treninga (tj. po tem, katera umska aktivnost je vsebina treninga), kako so treningi izvedeni (skupinsko, individualno), kje se trening izvaja (v računalniški učilnici, preko strežnika na domu), količini treninga (kako dolge so vadbe, kolikokrat na teden), navodilih za izvajanje treninga (samo pisno ali tudi $\mathrm{z}$ dodatnimi tolmačenji voditelja treninga), prisotnosti ali odsotnosti povratne informacije o pravilni rešitvi naloge, tem, kakšna je baterija testov in vprašalnikov za merjenje bližnjega in daljnega transfera, kakšna je kontrolna skupina (pasivna, aktivna) itd.

Ne glede na to, da še ni dokončnih ugotovitev glede učinkovitosti, trajanja in transfera učinkov RKT, pa lahko zanesljivo rečemo, da ne obstajajo negativni stranski učinki RKT. V šali bi lahko rekli, da je "kognitivni trening škodljiv le neumnosti”.

\section{Trajanje učinka RKT}

Redke študije na starejših so ocenile trajanje učinka RKT, zato je težko razumeti in zaključevati o ozadju trajnosti učinkov. Medtem ko so Stern idr. (2011) in Ballesteros idr. (2015) poročali o odsotnosti učinka RKT tri mesece po treningu, Buschkuehl idr. (2008) pa po enem letu, pa so na drugi strani Toril idr. (2016) poročali o izboljšanem delovnem spominu takoj po zaključku RKT in tri mesece kasneje. Podobno so Mahncke idr. (2006) ter Chambon idr. (2014) izmerili izboljšanje različnih vrst spomina tudi po KT/RKT. Zelinski idr. (2011) so poročali, da je slušni jezikovni trening, ki so ga opravili na velikem vzorcu starejših posameznikov $(N=487)$, izboljšal ne samo jezikovne funkcije, ampak tudi spominske sposobnosti, in to izboljšanje so izmerili tudi po treh mesecih. Willis idr. (2006) pa so celo poročali, da je KT z rabo logičnega sklepanja izboljšal kognitivne sposobnosti, ki so bile vključene v KT, in to izboljšanje se je kazalo celo 
po petih letih. Tudi v naši raziskavi (Marusic idr., 2015), ki smo jo izvedli na odraslih moških $\mathrm{z}$ učenjem virtualnega labirinta (za natančnejši opis tega RKT glej članek Marušiča in Kavčiča ter A. Knez idr. v tej številki Psiholoških obzorij), smo ugotovili, da je bilo pomembno boljše učenje virtualnega labirinta tudi po več kot enem letu.

Glede trajanja učinka KT/RKT lahko zaključimo, da imamo na razpolago vedno več empiričnih podatkov, ki kažejo, da se da vzdrževati pozitivne učinke KT/RKT tudi na daljši rok.

\section{Merjenje transfera oziroma generalizacije učinka KT}

Kot je bilo že nakazano, je osnovna predpostavka $\mathrm{KT} / \mathrm{RKT}$, da bo vadba izboljšala vadeno kognitivno sposobnost in se bo učinek vadbe generaliziral na tiste kognitivne sposobnosti, ki niso bile neposredno vključene $\mathrm{v}$ KT/RKT (Lampit idr., 2014). Raziskovalci običajno ocenijo učinkovitost KT/RKT z merjenjem različnih kognitivnih sposobnosti poleg sposobnosti, vključenih v KT/RKT. Večina študij poroča, da pri KT prihaja do bližnjega transfera, to je izboljšanja tistih umskih sposobnosti, ki so bile delno ali posredno vključene v KT/RKT, npr. ko se umske sposobnosti $\mathrm{v}$ okviru treninga in zaključnih meritev dokaj prekrivajo. Je pa šibka empirična podpora glede daljnega transfera, tj. izboljšanja rezultatov na testih tistih umskih sposobnosti, ki niso ali so le delno vključene v trening (Bürki idr., 2014; Taatgen, 2013). Čeprav je merjenje transfera enostavno, pa je razumevanje mehanizmov KT dokaj omejeno (Wolf idr., 2018).

Vprašanje transfera ni nič posebno novega $\mathrm{v}$ okviru $\mathrm{KT} / \mathrm{RKT}$, saj se je ta koncept pojavil z začetki znanstvene obravnave učenja. Simons idr. (2016) postavljajo izvor teoretičnega koncepta transfera $v$ začetno teorijo učenja, t. i. teorijo formalne discipline. Po tej teoriji bo uspeh vadbe na nekem kognitivnem področju na splošno prenesen na druge umske sposobnosti. Na tej podlagi se učimo matematiko, smo se na pamet učili pesmi oziroma so se ne tako dolgo nazaj učenci v šoli učili latinščino. Po tej teoriji naj bi se bila prenesla v razvoj intelektualnih sposobnosti in spretnosti tudi znanja, ki nimajo velike povezave z vsakdanjim življenjem.

Tej teoriji je sledila razlaga transfera s teorijo identičnih elementov, ki jo je razvil Thorndike $\mathrm{v}$ začetku 20. stoletja. Thorndike (1917) je zaključil, da je "um specializiran v veliko število neodvisnih kapacitet" (str. 246) in da:

"trening uma pomeni razvoj tisoče posebnih neodvisnih kapacitet, oblikovanje neštetih posebnih navad, kajti delovanje vsake umske kapacitete je odvisno od konkretnih podatkov, ki so vključeni $\mathrm{v}$ to delovanje. Izboljšanje katerekoli umske funkcije ali aktivnosti bo izboljšalo druge funkcije ali aktivnosti samo, če vsebujeta skupne elemente [...] Najbolj splošen in gotov izvor splošnega izboljšanja neke kapacitete je vadba večjega števila specifičnih povezav". (str. 248)

To besedilo predstavlja podlago za koncept "transfera identičnih elementov", po katerem so znanja in spretnosti, pridobljene $\mathrm{s}$ treningom, povezane $\mathrm{z}$ dražljaji, nalogo in odgovori med treningom.
Trenutno je ta pogled na transfer še vedno najbolj sprejet, saj večina raziskovalcev KT meni, da pride do izboljšanja netreniranih kognitivnih sposobnosti na podlagi podobnosti in/ali prekrivanja elementov treniranih in netreniranih nalog (Zinke idr., 2014). Podobno Jaeggi idr. (2010) menijo, da do odsotnosti transfera pride predvsem zaradi neskladnega načrtovanja nalog v okviru KT in izhodnih meritev, s katerimi preverjamo njegov učinek.

Novejši pristop $\mathrm{k}$ transferu tudi vedno bolj poudarja pomen okolja (konteksta) in prikrite vloge interakcije med učenjem in okoljem pri bližnjem in daljnem transferu (za pregled glej Schwaighofer idr., 2015). V metaanalizi so Schwaighofer idr. (2015) preverjali, ali sta učinkovitost in transfer različna, ko je vadba delovnega spomina umeščena v bolj kompleksne vaje, kot v primeru, če se specifično vadi samo delovni spomin (npr. z vajo 1-nazaj). Poročajo, da obstaja empirična podpora za trditev, da se na splošno umske sposobnosti izboljšajo in to izboljšanje traja dlje $\mathrm{z}$ vajami, ki so bolj kompleksne in vključujejo vadbo, ki zahteva več umskih sposobnosti, npr. preklapljanje, inhibicijo. Ti raziskovalci tudi menijo, da bi bile v bodoče potrebne študije, ki bi sistematično preučile vpliv kontekstnih moderatorjev na bližnji in daljni transfer. Na primer, preučiti bi bilo treba učinek lokacije treninga, tj. ali vadbo izvajamo v razredu, računalniški učilnici, doma ali preko spleta. Preučiti bi bilo treba tudi učinek izoliranosti trenirane funkcije, tj. tega, ali vadimo eno samo specifično umsko sposobnost ali je ta sposobnost umeščena v vaje, ki vključujejo tudi druge umske sposobnosti. Torej, predvidevamo lahko, da transfer ni odvisen samo od vsebine treninga, ampak tudi od podobnosti konteksta, v katerem se je KT izvajalo, in konteksta preverjanja umskih sposobnosti, kakor tudi od interakcije med vsebino in kontekstom. Schwaighofer idr. (2015) menijo, da lahko različnost konteksta med treningom in nevropsihološkim testiranjem pomembno vpliva na pomanjkanje daljnega transfera. Opozarjajo tudi, da specifična vadba delovnega spomina ni enaka vadbi rabe različnih strategij za izboljšanje delovnega spomina, kajti trening mnemoničnih strategij je odvisen tudi od drugih sposobnosti, ne le delovnega spomina. Poleg tega je trening mnemoničnih strategij odvisen tudi od konteksta.

V tej posebni temi Psiholoških obzorij več člankov govori o RKT z rabo virtualnega labirinta. Večina teh člankov poroča, da je RKT izboljšal predvsem storilnost na testu sledenja, in sicer na podtestu B, ki naj bi odražal predvsem izvršilne sposobnosti. V manjši meri so bili prisotni tudi izboljšani rezultati na spominskem testu Auditory-Verbal Learning Test (AVLT). Marusic idr. (2015) pa so poročali tudi o izboljšanju večopravilnosti po RKT z virtualnim labirintom. Enostavna razlaga transfera, izmerjenega $z$ omenjenimi testi, je, da so bile sposobnosti, za katere je bilo na nevropsiholoških testih značilno izboljšanje dosežkov, tiste sposobnosti, ki so bile uporabljene $\mathrm{v}$ procesu učenja labirinta. Takšna razlaga je smiselna, je pa nekoliko vprašljiva, saj zaenkrat še ne poznamo vseh sposobnosti, ki so vključene $v$ učenje virtualnega labirinta. Če že morda lahko vidimo podobnost odločanja, po katerem hodniku moramo nadaljevati pot, da pridemo do cilja, in odločanja o vrstnem redu črk in številk $\mathrm{V}$ podtestu $\mathrm{B}$ na testu sledenja, pa težje najdemo podobnost 
učenja virtualnega labirinta s testom istočasne hitre hoje in odštevanja nazaj. Kot navajajo avtorji teh člankov, učenje virtualnega labirinta angažira več umskih sposobnosti, predvsem pozornost, različne vrste spomina in izvršilne sposobnosti. Vadbo vidne navigacije $z$ virtualnim labirintom lahko obravnavamo kot kompleksen kontekst, kajti, kot smo omenili, ta vadba zahteva več kognitivnih sposobnosti, in tako bi po Schwaighoferju idr. (2015) lahko pričakovali, da trening $\mathrm{z}$ virtualnim labirintom omogoča več transfera, kajti pri učenju labirinta naj bi prišlo do rabe več kognitivnih sposobnosti in preklapljanja med njimi.

Projekti, ki se ukvarjajo s KT/RKT, niso pripravljeni prvenstveno za preučevanje mehanizma daljnega transfera, ampak za preverjanje učinkovitosti različnih vrst KT/RKT na različnih populacijah. Zaključke lahko delamo le na podlagi raziskav, ki so prvenstveno usmerjene v preučevanje učinkovitosti kognitivnih intervencij. V zadnjem času se pojavlja vedno več študij, ki bolj intenzivno raziskujejo dejavnike, ki vplivajo na daljni transfer. Tako so Bürki idr. (2014) poročali, da so dosežki na treningu odvisni od fluidne inteligentnosti posameznika, $\mathrm{z}$ drugimi besedami, tisti $\mathrm{z}$ višjimi fluidnimi sposobnostmi dosegajo večji napredek na treningu. Jeaggi idr. (2014) so poročali, da je transfer RKT delovnega spomina na fluidne sposobnosti odvisen od motivacije posameznika in njegove potrebe po kognitivnem angažiranju. Poleg tega so Jaeggi idr. (2014) poročali, da so med dejavniki transfera učinkov RKT, ki jih je potrebno upoštevati, poleg motivacije tudi starost ter osebnostne lastnosti. Colzato idr. (2013) so preverjali, kakšno vlogo pri učinkovitosti KT/RKT imajo genetski dejavniki. Njihova raziskava je pokazala, da so boljši transfer po akcijskih videoigrah na testih preklapljanja dosegli nosilci Val/Val gena, ki regulira nevrotransmiter dopamin, v primerjavi s tistimi, ki so bili nosilci Met gena, ki preko receptorja za tirozin kinazo kontrolira nevronsko diferenciacijo in rast.

Obstajata dve vrsti RKT. Jedrni trening (angl. core training) je usmerjen izključno na s ponavljajočo vadbo ciljano kognitivno sposobnost, npr. izključno na vaje za delovni spomin s ciljem izboljšanja delovnega spomina (npr. s specifično nalogo za krepitev spomina, npr. nalogo 2-nazaj), medtem ko trening strategij (angl. strategy training) vključuje vadbo različnih $\mathrm{s}$ kognitivno sposobnostjo povezanih strategij, da bi izboljšali sposobnost priklica večjega števila elementov. Na primer, pri vadbi epizodičnega delovnega spomina se udeleženci učijo različnih mnemoničnih tehnik, od kategoriziranja do metode mest, tj. metode asociiranja vsebine, ki si jo je treba zapomniti, s fizičnimi lokacijami (Morrison in Chein, 2011). Metaanaliza Heringa idr. (2014) je analizirala razliko med t. i. KT/RKT, ki je vključeval vadbo strategij, in KT/RKT, ki je vključeval vadbo procesa za izboljšanje prospektivnega spomina. Avtorji so zaključili, da je za izboljšanje prospektivnega spomina najboljša kombinacija obeh metod.

Daljni transfer je manj vprašljiv, če se pokaže tudi na drugih domenah, npr. pri nadzoru ravnotežja in/ali hoje ali pa psihološke dobrobiti. Tako smo v ortopedski bolnišnici Valdoltra na zdravih mlajših in starejših odraslih moških izvedli 14-dnevno študijo neprekinjenega ležanja brez vstajanja, med katerim so bile vse dnevne aktivnosti in higiena opravljene $\mathrm{v}$ horizontalnem položaju (angl. bed rest study) (Pišot idr., 2016; Soavi idr., 2016). Skupina starejših odraslih je bila naključno razdeljena v dve skupini, kontrolno, ki je gledala dokumentarne filme na TV, in intervencijsko, ki je izvedla 12 seans RKT (Marusic, Giordani idr., 2018; Marusic idr., 2015; Marusic idr., 2019). Po RKT so udeleženci iz intervencijske skupine pokazali pozitiven transfer na nadzor hoje. Natančneje, udeleženci, ki so opravili RKT, so po zaključku neprekinjenega ležanja $\mathrm{v}$ primerjavi $\mathrm{s}$ kontrolno skupino pokazali pomembno manjši upad med izvajanjem testa hitre hoje $\mathrm{z}$ dodatno kognitivno nalogo odštevanja nazaj po 3 (Marusic idr., 2015). Tudi Marusic, Verghese in Mahoney (2018) v metaanalitični pregledni raziskavi poročajo o podobnih ugotovitvah, da se daljni transfer RKT kaže $v$ boljšem nadzoru kompleksnih gibanj (najpogosteje hoji z dodatno kognitivno nalogo). Študije, ki so poročale o daljnem transferu izven kognitivne domene, so redkejše, so pa zato bolj prepričljiv dokaz daljnega transfera, čeprav ozadje in mehanizmi transfera še niso dobro poznani (Marusic idr., 2018; Marusic in Grosprêtre, 2018).

Zaključimo lahko, da obstaja med raziskovalci soglasje, da po KT/RKT skoraj vedno izmerimo bližnji transfer, doseganje daljnega transfera pa je vprašljivo. Zgornji opis na kratko omenja tiste pomembne dejavnike, ki naj bi vplivali na daljni transfer po KT, kamor sodijo parametri samega treninga, vsebina treninga, metode merjenja transfera, kontekst in značilnosti udeležencev treninga.

\section{Nevroplastičnost - nevronska podlaga učinka KT/RKT}

Ko govorimo o plastičnosti v okviru KT/RKT, je treba razlikovati med kognitivno plastičnostjo in nevroplastičnostjo. Kognitivna plastičnost je opredeljena kot posameznikova kapaciteta za izboljšanje kognitivnih sposobnosti (lahko bi tudi rekli latentni umski potencial) (Willis in Shaie, 2009), nevroplastičnost pa je opredeljena kot sposobnost možganov, da ustvarijo nove sinapse in/ ali sinaptične povezave kot odziv na učenje ali življenjske izkušnje. Ali drugače rečeno, plastičnost na splošno opredelimo kot sposobnost spreminjanja strukture ali funkcije kot posledice zunanjih dražljajev. Nevroplastičnost je potencial, ki se realizira samo, ko smo soočeni $\mathrm{s}$ povečanimi kognitivnimi zahtevami (Park in Bischof, 2013).

Nevroplastičnost se $\mathrm{v}$ ožjem pomenu besede nanaša na izboljšanje nevronskega delovanja možganov in razvoj novih struktur, novih povezav, kar pomaga kognitivnemu funkcioniranju. To povečano možgansko delovanje se kaže v spremembi prostornine tistih delov možganov, ki so aktivirani med KT/RKT, kot najbolj zanesljivem kazalcu delovanja KT/RKT, tj. odzivu možganov na povečane kognitivne zahteve KT/RKT. Rezultatov o učinkih KT/ RKT na nevroplastičnost je zaenkrat malo in so tudi dokaj variabilni. Boyke idr. (2008) so tako pri mlajših kot starejših udeležencih poročali o povečani prostornini medialnih temporalnih področij, hipokampusa in nukleusa akumbensa po 90-dnevnem treningu žongliranja. Povečala se je prostornina tistih možganskih delov, ki so bili med treningom udeleženi $\mathrm{v}$ vidnem in motoričnem procesiranju. 
Podobno so Lövdén idr. (2012) poročali, da je pri starejših udeležencih (pri katerih je zmanjšanje prostornine hipokampusa normativno), ki so trikrat na teden v roku štirih mesecev vadili navigacijo $\mathrm{v}$ virtualnem zoološkem vrtu, prostornina hipokampusa ostala nespremenjena, medtem ko se je pri udeležencih iz kontrolne skupine pomembno zmanjšala.

V zadnjem času je tudi vse več poročil, ki kažejo, da je KT povezan s spremembami nevronske aktivacije $\mathrm{v}$ tistih kortikalnih predelih, ki so najbolj pomembni za uspešno izvajanje KT. Belleville idr. (2011) so poročali, da je po mnemoničnem treningu pri starejših udeležencih prišlo do zmanjšanja kortikalne aktivnosti med vkodiranjem in do povečanja aktivacije pri priklicu. Do sprememb nevronske aktivacije je prišlo tako pri zdravih starejših (Belleville idr., 2014) kot tudi pri tistih starejših, ki so bili diagnosticirani z blago kognitivno motnjo (Belleville idr., 2011). Podobno je Nyberg (2005) poročal, da je mnemonični trening pri mlajših in tudi starejših udeležencih pokazal povečano aktivacijo v parietalno-okcipitalnih predelih, ampak samo pri tistih, ki so pokazali transfer treninga na vedenjski ravni. Tudi Carlson idr. (2009) so poročali, da so starejši, ki so bili aktivno udeleženi v programu Experience Corps Program (tj. programu vključevanja starejših v podporne in literarne aktivnosti $\mathrm{z}$ učitelji osnovnih šol), pokazali izboljšanje izvršilnih funkcij in povečano aktivnost $\mathrm{v}$ prefrontalnem delu. Mozolic idr. (2010) pa so za merjenje možganskih sprememb, povezanih s KT, uporabili možgansko prekrvavitev in poročali, da so po 6-tedenskem KT pozornosti pri starejših odraslih, ki so opravljali nalogo pozornosti, opazili zmanjšano odkrenljivost in povečano prekrvavitev v prefrontalni regiji med počitkom. Predpostavlja se, da ponavljanje določenih standardiziranih nalog, ki so sestavni del KT, vpliva na izboljšanje sinaptičnega funkcioniranja in sinaptogeneze.

Nasprotno so Brehmer idr. (2008) poročali, da je prišlo pri starejših po 5-tedenskem adaptivnem KT delovnega spomina, pri katerem se je težavnost nalog stopnjevala glede na uspešnost posameznika, do znižanja nevronske aktivacije $\mathrm{v}$ frontalnih, parietalnih in okcipitalnih regijah. Po mnenju avtorjev naj bi znižanje nevronske aktivacije kazalo na izboljšano učinkovitost delovanja možganov in tudi na manjšo rabo možganskih resursov.

Obstajajo tudi študije, ki poročajo, da je poleg spremenjene nevronske prostornine in nevronske aktivacije po RKT, ki naj bi predstavljala mehanizem nevroplastičnosti, RKT vplival tudi na povečano konektivnost možganske mreže, ki je podlaga za izvršilne funkcije - povečala se je frakcijska anisotropičnost v levem uncinatu (Chapman idr., 2015). O povečani frakcijski anisotropičnosti po vadbi delovnega spomina $\mathrm{v}$ intraparietalnem sulkusu in anteriornem korpusu kalosumu so poročali Takeuchi idr. (2010). Bäckman idr. (2011) pa so poročali o povečani količini nevrotransmiterja dopamina v striatumu po RKT.

Skratka, obstaja cela vrsta možganskih procesov, ki so občutljivi za RKT, in so dokazana podlaga za nevroplastičnost. Če gledamo na RKT z nevroplastičnega vidika, lahko z RKT ciljamo na specifične možganske procese, da bi bodisi izboljšali nekatere od njih bodisi preprečili slabšanje možganskih struktur in funkcij ter tako preprečili umske upade predvsem pri starejših.

\section{Zaključek}

Ta kratek uvod v posebno številko Psiholoških obzorij o kognitivnih treningih predstavlja veliko znanega o KT in RKT. Vendar še vseeno ni znanega dovolj, da bi z gotovostjo lahko zaključili, na podlagi katerih značilnosti treninga in dejavnikov lahko načrtujemo RKT, ki bo uspešen predvsem $\mathrm{z}$ vidika transfera, to je izboljšanja netreniranih kognitivnih sposobnosti in/ali celo življenjske dobrobiti ter opravljanja vsakodnevnih aktivnosti. Torej, potrebnih bo še kar nekaj študij, ki bodo še natančneje preučile vse potrebne lastnosti KT za njegovo učinkovitost in trajnejši uspeh, kakor tudi študij, ki bodo natančneje preučile izbor izhodnih mer učinkov treninga, ki dajo zanesljive in veljavne ugotovitve. Tako kot na večini psiholoških področij je tudi razvoj na tem področju vse hitrejši. Ugotovitve takšnih študij bodo dobrodošle za vse bodoče raziskovalce, ki se bodo lotili KT/ RKT, pa tudi za izvajalce KT/RKT v praksi. Ne glede na trenutno stanje pa je področje KT/RKT obetavno področje psihologije, nevroznanosti in sorodnih disciplin, ki lahko veliko prispeva posamezniku in družbi.

\section{Literatura}

Anguera, J. A. in Gazzaley, A. (2015). Video games, cognitive exercises, and the enhancement of cognitive abilities. Current Opinion in Behavioral Sciences, 4, 160-165.

Bäckman, L., Nyberg, L., Soveri, A., Johansson, J., Andersson, M., Dahlin, E., Neely, A. S., Virta, J., Laine, M. in Rinne, J. O. (2011). Effects of working-memory training on striatal dopamine release. Science, 333(6043), 718.

Bahar-Fuchs, A., Martyr, A., Goh, A. M., Sabates, J. in Clare, L. (2019). Cognitive training for people with mild to moderate dementia. Cochrane Database of Systematic Reviews.

Ballesteros, S., Mayas, J., Prieto, A., Toril, P., Pita, C., Ponce De León, L., Reales, J. M. in Waterworth, J. A. (2015). A randomized controlled trial of brain training with nonaction video games in older adults: Results of the 3-month follow-up. Frontiers in Aging Neuroscience, 7, 1-12.

Beck, C., Heacock, P., Mercer, S., Thatcher, R. in Sparkman, C. (1988). The impact of cognitive skills remediation training on persons with Alzheimer's disease or mixed dementia. Journal of Geriatric Psychiatry, 21(1), 73-88.

Belleville, S., Clement, F., Mellah, S., Gilbert, B., Fontaine, F. in Gauthier, S. (2011). Training-related brain plasticity in subjects at risk of developing Alzheimer's disease. Brain, 134(6), 1623-1634.

Belleville, S., Mellah, S., de Boysson, C., Demonet, J. F. in Bier, B. (2014). The pattern and loci of training-induced brain changes in healthy older adults are predicted by the nature of the intervention. PloS One, 9(8), članek e102710. 
Boyke, J., Driemeyer, J., Gaser, C., Büchel, C. in May, A. (2008). Training-induced brain structure changes in the elderly. Journal of Neuroscience, 28(28), 7031-7035.

Brehmer, Y., Li, S.-C., Straube, B., Stoll, G., von Oertzen, T., Müller, V. in Lindenberger, U. (2008). Comparing memory skill maintenance across the life span: Preservation in adults, increase in children. Psychology and Aging, 23(2), 227-238.

Bürki, C. N., Ludwig, C., Chicherio, C. in de Ribaupierre, A. (2014). Individual differences in cognitive plasticity: An investigation of training curves in younger and older adults. Psychological Research, 78(6), 821-835.

Buschkuehl, M., Jaeggi, S. M., Hutchison, S., Perrig-Chiello, P., Däpp, C., Müller, M., Breil, F., Hoppeler, H. in Perrig, W. J. (2008). Impact of working memory training on memory performance in old-old adults. Psychology and Aging, 23(4), 743-753.

Carlson, M. C., Erickson, K. I., Kramer, A. F., Voss, M. W., Bolea, N., Mielke, M., McGill, S., Rebok, G. W., Seeman, T. in Fried, L. P. (2009). Evidence for neurocognitive plasticity in at-risk older adults: The experience corps program. The Journals of Gerontology, Series A: Biomedical Sciences and Medical Sciences, 64(12), 1275-1282.

Chambon, C., Herrera, C., Romaiguere, P., Paban, V. in Alescio-Lautier, B. (2014). Benefits of computer-based memory and attention training in healthy older adults. Psychology and Aging, 29, 731-743.

Chapman, S. B., Aslan, S., Spence, J. S., Hart, J. J., Jr., Bartz, E. K., Didehbani, N., Keebler, M. W., Gardner, C. M., Strain, J. F., DeFina, L. F. in Lu, H. (2015). Neural mechanisms of brain plasticity with complex cognitive training in healthy seniors. Cerebral cortex, 25(2), 396-405.

Colzato, L. S., van den Wildenberg, W. P., Zmigrod, S. in Hommel, B. (2013). Action video gaming and cognitive control: Playing first person shooter games is associated with improvement in working memory but not action inhibition. Psychological Research, 77(2), 234-239.

Diller, L., Weinberg, J., Gordon, W., Goodkin, R., Gerstman, L. J. in Ben-Yishay, Y. (1974). Studies in cognition and rehabilitation in hemiplegia. Behavioral Science, Institute of Rehabilitation Medicine, New York University Medical Center.

Elias, J. W. in Wagster, M. V. (2007). Developing context and background underlying cognitive intervention/ training studies in older populations. The Journals of Gerontology, Series B: Psychological Sciences and Social Sciences, 62, 5-10.

Hannan, A. J. (2014). Environmental enrichment and brain repair: Harnessing the therapeutic effects of cognitive stimulation and physical activity to enhance experiencedependent plasticity. Neuropathology and Applied Neurobiology, 40(1), 13-25.

Hering, A., Rendell, P. G., Rose, N. S., Schnitzspahn, K. M. in Kliegel, M. (2014). Prospective memory training in older adults and its relevance for successful aging. Psychological Research, 78(6), 892-904.
Jaeggi, S. M., Buschkuehl, M., Shah, P. in Jonides, J. (2014). The role of individual differences in cognitive training and transfer. Memory \& Cognition, 42(3), 464-480.

Jaeggi, S. M., Studer-Luethi, B., Buschkuehl, M., Su, Y. F., Jonides, J. in Perrig, W. J. (2010). The relationship between n-back performance and matrix reasoningImplications for training and transfer. Intelligence, 38(6), 625-635.

Katz, B., Shah, P. in Meyer, D. E. (2018). How to play 20 questions with nature and lose: Reflections on 100 years of brain-training research. Proceedings of the National Academy of Sciences, 115(40), 9897-9904.

Kavčič, V. (2015). Umovadba: Za bistre možgane v poznih letih [Mind training: For sharp brains in old age]. Miš.

Lampit, A., Hallock, H., Suo, C., Naismith, S. L. in Valenzuela, M. (2015). Cognitive training-induced shortterm functional and long-term structural plastic change is related to gains in global cognition in healthy older adults: A pilot study. Frontiers in Aging Neuroscience, 7, članek 14.

Lampit, A., Hallock, H. in Valenzuela, M. (2014). Computerized cognitive training in cognitively healthy older adults: A systematic review and meta-analysis of effect modifiers. PLoS Medicine, 11(11), članek el001756.

Lövdén, M., Schaefer, S., Noack, H., Bodammer, N. C., Kühn, S., Heinze, H. J., Düzel, E., Bäckman, L. in Lindenberger, U. (2012). Spatial navigation training protects the hippocampus against age-related changes during early and late adulthood. Neurobiology of Aging, 33(3), 620.e9-620.e22.

Mahncke, H. W., Connor, B. B., Appelman, J., Ahsanuddin, O. N., Hardy, J. L., Wood, R. A., Joyce, N. M., Boniske, T., Atkins, S. M. in Merzenich, M. M. (2006). Memory enhancement in healthy older adults using a brain plasticity based training program: A randomized, controlled study. Proceedings of the National Academy of Sciences of the United States of America, 103(33), 12523-12528.

Marusic, U., Giordani, B., Moffat, S. D., Petrič, M., Dolenc, P., Pišot, R. in Kavcic, V. (2018). Computerized cognitive training during physical inactivity improves executive functioning in older adults. Aging, Neuropsychology, and Cognition, 25(1), 49-69.

Marusic, U. in Grosprêtre, S. (2018). Non-physical approaches to counteract age-related functional deterioration: Applications for rehabilitation and neural mechanisms. European Journal of Sport Science, 18(5), 639-649.

Marusic, U., Kavcic, V., Giordani, B., Gerževič, M., Meeusen, R. in Pišot, R. (2015). Computerized spatial navigation training during 14 days of bed rest in healthy older adult men: Effect on gait performance. Psychology and Aging, 30(2), 334-340.

Marusic, U., Kavcic, V., Pisot, R. in Goswami, N. (2019). The role of enhanced cognition to counteract detrimental effects of prolonged bed rest: Current evidence and perspectives. Frontiers in Physiology, 9, članek 1864.

Marusic, U., Verghese, J. in Mahoney, J. R. (2018). Cognitivebased interventions to improve mobility: a systematic review and meta-analysis. Journal of the American Medical Directors Association, 19(6), 484-491. 
Morrison, A. B. in Chein, J. M. (2011). Does working memory training work? The promise and challenges of enhancing cognition by training working memory. Psychonomic Bulletin \& Review, 18(1), 46-60.

Mozolic, J. L., Hayasaka, S. in Laurienti, P. J. (2010). A cognitive training intervention increases resting cerebral blood flow in healthy older adults. Frontiers in Human Neuroscience, 4, članek 16.

Neely, A. S., Vikström, S. in Josephsson, S. (2009). Collaborative memory intervention in dementia: Caregiver participation matters. Neuropsychological Rehabilitation, 19(5), 696-715.

Nyberg, L. (2005). Cognitive training in healthy aging: A cognitive neuroscience perspective. V R. Cabeza, L. Nyberg in D. Park (ur.), Cognitive neuroscience of aging: Linking cognitive and cerebral aging (str. 309-321). Oxford University Press.

Park, D. C. in Bischof, G. N. (2013). The aging mind: Neuroplasticity in response to cognitive training. Dialogues in Clinical Neuroscience, 15(1), 109-119.

Pišot, R., Marusic, U., Biolo, G., Mazzucco, S., Lazzer, S., Grassi, B., Reggiani, C., Taniolo, L., di Prampero, P. E., Passaro, A., Narici, M., Mohammed, S., Rittweger, J., Gasparini, M., Gabrijelčič Blenkuš, M. in Šimunič, B. (2016). Greater loss in muscle mass and function but smaller metabolic alterations in older compared with younger men following 2 wk of bed rest and recovery. Journal of Applied Physiology, 120(8), 922-929.

Sala, G., Aksayli, N. D., Tatlidil, K. S., Tatsumi, T., Gondo, Y. in Gobet, F. (2019). Near and far transfer in cognitive training: A second-order meta-analysis. Collabra: Psychology, 5(1), članek 18.

Schwaighofer, M., Fischer, F. in Bühner, M. (2015). Does working memory training transfer? A metaanalysis including training conditions as moderators. Educational Psychologist, 50(2), 138-166.

Simons, D. J., Boot, W. R., Charness, N., Gathercole, S. E., Chabris, C. F., Hambrick, D. Z. in Stine-Morrow, E. A. (2016). Do "brain-training" programs work? Psychological Science in the Public Interest, 17(3), 103-186.

Soavi, C., Marušič, U., Sanz, J. M., Morieri, M. L., Dalla Nora, E., Šimunič, B., Pišot, R., Zuliani, G. in Passaro, A. (2016). Age-related differences in plasma BDNF levels after prolonged bed rest. Journal of Applied Physiology, 120(10), 1118-1123.

Stern, Y., Blumen, H., Rich, L., Richards, A., Herzberg, G. in Gopher, D. (2011). Space fortress game training and executive control in older adults: A pilot intervention. Aging Neuropsychology, and Cognition, 18, 653-677.

Taatgen, N. A. (2013). The nature and transfer of cognitive skills. Psychological Review, 120(3), 439-471.

Takeuchi, H., Sekiguchi, A., Taki, Y., Yokoyama, S., Yomogida, Y., Komuro, N., Yamanouchi, T., Suzuk, S. in Kawashima, R. (2010). Training of working memory impacts structural connectivity. Journal of Neuroscience, 30(9), 3297-3303.

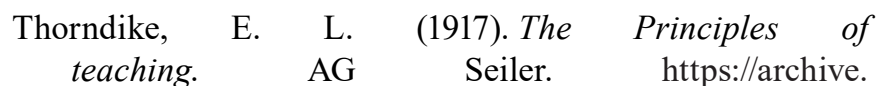
org/details/principlesofteac00thor/page/220/mode/2up

Toril, P., Reales, J. M., Mayas, J. in Ballesteros, S. (2016). Video game training enhances visuospatial working memory and episodic memory in older adults. Frontiers in Human Neuroscience, 10, članek 206.

Willis, S. L. in Schaie, K. W. (2009). Cognitive training and plasticity: Theoretical perspective and methodological consequences. Restorative Neurology and Neuroscience, 27(5), 375-389.

Willis, S. L., Tennstedt, S. L., Marsiske, M., Ball, K., Elias, J., Koepke, K. M., Morris, J. N., Rebok, G. W., Unverzagt, F. W., Stoddart, A. M. in Wright, E. (2006). Long-term effects of cognitive training on everyday functional outcomes in older adults. Jama, 296(23), 2805-2814.

Wolf, D., Tüscher, O., Teipel, S., Mierau, A., Strüder, H., Drzezga, A., Baier, B., Binder, H., Fellgiebel, A. in the German AgeGain study group. (2018). Mechanisms and modulators of cognitive training gain transfer in cognitively healthy aging: Study protocol of the AgeGain study. Trials, 19, 337.

Zarit, S. H., Cole, K. D. in Guider, R. L. (1981). Memory training strategies and subjective complaints of memory in the aged. The Gerontologist, 21(2), 158-164.

Zelinski, E. M., Spina, L. M., Yaffe, K., Ruff, R., Kennison, R. F., Mahncke, H. W. in Smith, G. E. (2011). Improvement in memory with plasticity-based adaptive cognitive training: Results of the 3-month follow-up. Journal of the American Geriatrics Society, 59(2), 258-265.

Zinke, K., Zeintl, M., Rose, N. S., Putzmann, J., Pydde, A. in Kliegel, M. (2014). Working memory training and transfer in older adults: Effects of age, baseline performance, and training gains. Developmental Psychology, 50(1), 304-315. 